\title{
GENETIC PARAMETERS ESTIMATE FOR PLANT CHARACTERS OF A PARTICULAR CARROT POPULATION IN TWO DIFFERENT AGROECOLOGIC CULTIVATION SYSTEMS
}

\author{
PARÂMETROS GENÉTICOS ESTIMADOS PARA CARACTERES DE PLANTA DE \\ UMA POPULAÇÃO PARTICULAR DE CENOURA EM DOIS SISTEMAS DE \\ CULTIVO AGROECOLÓGICO DIFERENTES
}

\author{
Michelle Souza VILELA ${ }^{1}$; José Ricardo PEIXOTO' ${ }^{1}$; Jairo Vidal VIEIRA ${ }^{2}$; \\ Giovani Olegário da SILVA ${ }^{2}$; Daiane da Silva NÓBREGA ${ }^{\mathbf{1}}$; Rosa Maria de Deus de SOUSA ${ }^{\mathbf{1}}$ \\ 1. Faculty of Agronomy and Veterinary Medicine, University of Brasília, Brasília, DF, Brazil. michellevilelaunb@gmail.com; 2. \\ Brazilian agricultural research company, Embrapa vegetables, Brasília, DF, Brazil.
}

\begin{abstract}
Carrots are among the most planted vegetables in Brazil, which represents importance in the national market. This crop can be grown in conventional and agroecological systems, and studies to improve productivity, disease resistance and root quality in agroecological cropping systems are important. The aim of the present work was to estimate genetic parameters that provide a breeding strategy in the search for the development of new varieties of carrot adapted to the conditions of Distrito Federal's agroecology cultivation. Considering data from tests performed in areas of agroecology cultivation (Natural Agriculture-NA and Organic Agriculture-OA), the following characteristics were evaluated: incidence of leaf blight-LB, incidence of root cracking-CRACK, root length-COMP, format of root tip-TP, format of root shoulder-TO, measure of the color of the $a^{*}$ xylem parameter-a*X, measure of the color of the $a^{*}$ phloem parameter-a*F. Traits were evaluated in 100 half-sib progenies derived from Brasília cultivar, using a completely randomized block design. For the characters COMP, $\mathrm{a}^{*} \mathrm{X}, \mathrm{a}^{*} \mathrm{~F}, \mathrm{TP}$ and $\mathrm{TO}$, the treatment $\mathrm{X}$ environment interaction was significant according to the results from test $\mathrm{F}$. The values of the individual variance analyses presented significant effect for the following characteristics: COMP, $a^{*} \mathrm{X}, \mathrm{TP}, \mathrm{TO}, \mathrm{LB}$ for NA system, and COMP, $\mathrm{a}^{*} \mathrm{X}, \mathrm{a}^{*} \mathrm{~F}, \mathrm{TP}$ for OA system. In NA system, the values of heritability estimates-ha ${ }^{2}$ for the plant characters fluctuated from 65.66 to $25.52 \%$ and, in the OA system, the ha ${ }^{2}$ of the characters $\mathrm{a}^{*} \mathrm{X}$, was $81.13 \%$. Estimates of genetic gain per cycle for the characters $\mathrm{a}^{*} \mathrm{X}$ and $\mathrm{a} * \mathrm{~F}$ were lower in NA system than the estimates observed in OA system.
\end{abstract}

KEYWORDS: Daucus carota. Genetic breeding. Heritability.

\section{INTRODUCTION}

The carrot (Daucus carota L.) is among the five most important vegetable crops in Brazil, considering the crop area or value of production (MAROUELLI; OLIVEIRA; SILVA, 2007; RESENDE; BRAGA, 2014). There is increasing among consumers the demand for better quality of carrot roots associated with the use of cultivars with good sustainability of cultivation, in search of a healthier diet and products with good visual quality and nutrition, free of pesticide residues and even with some functional properties. Due to these demands, in particular the interest in products with low levels of pesticide residues and produce less aggressive to the environment, agroecology agriculture and its derivatives has been growing rapidly worldwide (LOPES; LOPES, 2011). However, today this type of product represents a small part of the food market, mainly characterized by consumers with higher purchasing power and higher educational level (ANDRADE; BERTOLDI, 2012).

As differences between the conventional and the agroecological cultivation, the law $\mathrm{n}^{\mathrm{o}} 659-\mathrm{A}$ (articles 1 and 2), of 1999, presents the definition of the term organic farming as a production system using specific techniques, which will minimize the use of natural and socioeconomic resources in order to promote the ecological and economic sustainability, increase social benefits, reduce or eliminate dependence on non-renewable energy and sisntéticos inputs, protecting people and the environment. Regarding genetic improvement, Van Bueren et al. (1999) note that the main differences in the breeding process for organic and conventional tillage systems are related to crop rotation practices, soil management, and diseases that normally use chemicals. These factors, if not considered, may provide differences in phenotype, performance, of improved cultivars in conventional fields and then validated in organic fields. 
Additionally, problems such as lower productivity of the agroecosystem compared to the conventional system, the reduced availability of technological information on organic production systems and the lack of information on a scientific basis to enable increase understanding of them, among other things, hinder the development of an organic system truly sustainable and competitive (CARDOSO; JOVCHELEVICH; MOREIRA, 2012). In Brazil, the breeding for the development of carrot cultivars adapted for cultivation in agroecological systems are weak. Most of the research is directed towards validation of cultivars developed primarily for conventional systems in terms of organic farming (RESENDE; VIEIRA; VIDAL, 2005). Thus, studies on obtaining estimates of genetic parameters for the main characters of interest are indispensable during the process of upgrading to agroecosystems. The objective of this study was to obtain estimates of genetic parameters for the definition of a best improvement strategy to be adopted in the development of new carrot cultivars adapted to agroecological growing conditions of Federal District.

\section{MATERIAL AND METHODS}

In summer 2006/2007, two trials were conducted in agroecological farming areas in the Federal District, Foundation Mokiti Okada Brazlândia - DF, following the guidelines of Natural Agriculture - NA and in Rural Core Taguatinga $\mathrm{DF}$, following the principles of Organic Agriculture - OA.

Each test consisted of 100 families of halfsiblings of a population derived from the cultivar Alvorada, arranged in a randomized complete block design with two replications. The plot size was $1 \mathrm{~m}^{2}$ area. Sowing was done in four lines transverse to the length of the plot, spaced $25 \mathrm{~cm}$, totaling approximately 100 plants per $\mathrm{m}^{2}$. The driving test has been delegated to producers, and the cultural practices, including fertilization and planting cover performed according to guidelines of each agroecological production system. It is worth mentioning that both trials was conducted thinning with approximately 30 days after sowing, however, the property of the Rural Core Taguatinga not observed the minimum distance between plants at thinning as recommended for conventionally grown carrot.

At 90 days after sowing was carried out at each site, an assessment of the level of incidence of leaf blight (LB) in each plot, using a criterion for grading in the range from 1 (susceptible) to 5 (strong) as methodology adapted by Aguillar, Reifschneider and Pessoa (1986).

At harvest, a sample of 20 competitive plants per plot, per replication, was obtained. Each plant was evaluated for the following characters: As the diagram adapted from Vieira et al. (2007) were evaluated: type tip (TP) - 1. round 2. slightly tapered and 3. tapered and type of shoulder (TO) - 1 . slightly tapered, 2. round 3. plan and 4. slightly concave. It was also evaluated the occurrence of crack (CRACK) - the number of roots to crack. And measured in centimeters: root length (COMP) - the outer leaves to the tip of the root. The color of the roots were determined using a Tristimulus color analyzer compact Minolta CR-200b (Minolta Corporation Instrument System Division) as measured using the color parameter a $*$ CIELAB system, which determines the content of $\beta$-carotene carrot roots (PEREIRA, 2002). To this end, each root was washed and cut transversely to length in the middle of its length, becoming then reading the color of xylem $\left(a^{*} \mathrm{X}\right)$ by direct measurement, putting the color analyzer equipment in contact with root tissue. The phloem color $\left(\mathrm{a}^{*} \mathrm{~F}\right)$ was also obtained directly after completion of a cut $2-3 \mathrm{~mm}$ thick along the length of the root. For all the characters was used the average value corresponding to the portion.

The data were analyzed to assess homogeneity of variance (Bartllet test) and normality (Lilliefors) for each system individually, and homogeneity of variance between the two systems. To meet the assumption of normal distribution, some characters were changed by root of $x$ and root of $x+0.5$. A joint analysis of variance was subsequently performed. Then there was the analysis of variance for each system, with information between plots. The heritability for mean square was estimated the relationship between the coefficient of genetic and environmental $(\mathrm{CVg} /$ $\mathrm{CVe}$ ) and the gains by selection were also calculated (GS) directly between families. All statistical operations were performed using the package Genes Program (CRUZ, 2013).

\section{RESULTS AND DISCUSSION}

The joint variance analyses of the data obtained from tests conducted in two agroecological farming systems: Natural Farming - NA and Organic Farming - OA for root traits, were based on average of parcels. The characters: length (COMP), a* parameter of the xylem of the root $\left(a^{*} X\right), a^{*}$ parameter of the phloem of the root $\left(a^{*} \mathrm{~F}\right)$, the type of the root tip format (TP) and type format 
shoulder of the root (TO), showed interaction families $x$ production system significantly by $F$ test in analysis of variance. For these characters, analyzes of variance were performed separately for each agroecosystem.

Analyses of variance of data obtained from testing conducted at the Foundation Mokiti Okada (NA) showed significant effects for the families to the characters COMP, a $*$ X, TP, TO and LB. This indicates that at least one family responded differently in relation to the other half-sibling progenies within each population. It can be observed that in general the coefficients of variation were low (ranging from $5.468 \%$ to $13.286 \%$ ), indicating good experimental precision.

Estimates of genetic parameters for plant traits for the system of Natural Agriculture (NA) are shown in Table 1. In general, estimates of heritability showed medium magnitude values. The heritability estimate for the character COMP in natural farming system (NA) (65.661\%) was similar to those obtained by Vieira et al. (2009) with value of $63 \%$ and $94 \%$, in conventional systems, for families of carrot in two years of evaluation. For all traits, the values of the ratio between genetic variation and environmental variation coefficient, were lower than 1. According to Pereira et al. (2012), values of this magnitude indicate that the use of simple mass selection and breeding do not provide significant gains during the selection process. In this study, considering the good experimental precision, the relations below 1 indicate low genotypic variability among progenies.

Table 1. Estimates of variances phenotypic (Vf), genotypic (Vg), environmental (Ve), broad sense heritability $\left(\mathrm{ha}^{2}\right)$, coefficient of genetic variation $(\mathrm{CVg})$ and coefficient of variation ratio between genetic and environmental $(\mathrm{CVg} / \mathrm{CVe})$, using test data conducted at Mokiti Okada Foundation - Natural Agriculture (NA) and Rural Core Taguatinga - Organic Agriculture (OA), for plant traits of carrot.

Mokiti Okada Fundatio - Natural Agriculture (NA)

\begin{tabular}{llllllll}
\hline Genetic Parameters & $\mathrm{COMP}$ & $\mathrm{A} * \mathrm{X}$ & $\mathrm{a} * \mathrm{~F}$ & $\mathrm{TP}$ & $\mathrm{TO}$ & $\mathrm{LB}$ & $\mathrm{CRACK}$ \\
\hline $\mathrm{V}_{\mathrm{f}}$ (average) & 1.964 & 0.055 & 0.043 & 0.055 & 0.040 & 0.008 & 0.142 \\
$\mathrm{~V}_{\mathrm{e}}$ (average) & 0.674 & 0.034 & 0.039 & 0.034 & 0.027 & 0.004 & 0.106 \\
$\mathrm{~V}_{\mathrm{g}}$ (average) & 1.289 & 0.020 & 0.003 & 0.022 & 0.012 & 0.003 & 0.036 \\
$\mathrm{~h}_{\mathrm{a}}{ }^{2} \%$ (average) & 65.661 & 37.053 & 8.261 & 39.194 & 30.294 & 39.112 & 25.526 \\
$\mathrm{CV}_{\mathrm{g}}$ & 7.736 & 3.427 & 1.286 & 7.543 & 5.698 & 3.099 & 16.342 \\
$\mathrm{CV}_{\mathrm{g}} / \mathrm{CV}_{\mathrm{e}}$ & 0.977 & 0.542 & 0.212 & 0.567 & 0.466 & 0.566 & 0.414 \\
\hline
\end{tabular}

Rural Core Taguatinga - Organic Agriculture (OA)

\begin{tabular}{llllllll}
\hline Genétic Parameters & COMP & $\mathrm{a}^{*} \mathrm{X}$ & $\mathrm{a}^{*} \mathrm{~F}$ & $\mathrm{TP}$ & $\mathrm{TO}$ & - & - \\
\hline $\mathrm{V}_{\mathrm{f}}$ (average) & 2.095 & 1.967 & 1.163 & 0.004 & 0.007 & - & - \\
\hline $\mathrm{V}_{\mathrm{e}}$ (average) & 0.984 & 0.371 & 0.592 & 0.002 & 0.002 & - & - \\
\hline $\mathrm{V}_{\mathrm{g}}$ (average) & 1.110 & 1.596 & 0.570 & 0.002 & 0.005 & - & - \\
\hline $\mathrm{h}_{\mathrm{a}}{ }^{2} \%$ (average) & 53.002 & 81.133 & 49.029 & 51.408 & 69.768 & - & - \\
\hline $\mathrm{CV}_{\mathrm{g}}$ & 7.321 & 6.444 & 3.389 & 3.030 & 4.343 & - & - \\
\hline $\mathrm{CV}_{\mathrm{g}} / \mathrm{CV}_{\mathrm{e}}$ & 0.750 & 1.466 & 0.693 & 0.727 & 1.074 & - & -
\end{tabular}

COMP: average root length per plot $(\mathrm{cm}), \mathrm{a}^{*} \mathrm{X}$ : the $\mathrm{a}^{*}$ average color of the xylem per plot, $\mathrm{a}^{*} \mathrm{~F} *$ : the $\mathrm{a}^{*}$ average color to the phloem per plot, TP: type of tip, TO: type of shoulder, LB: leaf blight and CRACK: crack.

The estimates of heritability for $\mathrm{a}^{*} \mathrm{X}$ and $\mathrm{a}^{*} \mathrm{~F}$ found that the estimates were near to those observed by Silva and Vieira (2010b) using data from conventional cultivation. These characters are strictly related to the content of carotenoids in carrot roots according to Pereira (2002). Thus, breeding programs aimed at increasing carotenoids in carrot sibling families can use these color characteristics as a basis for selection.

As regards the leaf blight (LB) according to Table 1, the heritability of NA culture system was low and with similar magnitude to those found by Silva et al. (2009), in two studied populations of carrot, using the conventional systems, which suggests little genetic variability in populations of Brasilia group for this character, or major environmental effect. In agroecosystems, may be related to low pressure of inoculum in the field during the evaluation period of the disease and can be attributed to factors such as the inability to use artificial inoculation of the disease; system of crop rotation employed and harvest system which eliminates all rest of the culture at the end of the cycle. According to Vieira et al. (2007), in organic systems, generally, the plants are harvested without "breaking" the leaves, and if they are without 
symptoms of these diseases are sold in "packs". Otherwise, the sheets are detached and used to produce organic compounds contributing to decrease the amount of inoculum in the field. The non-occurrence of symptoms of burning of leaves, in the system of organic agriculture (OA), may be a result of this practice.

The ratio of the genetic and environmental coefficient (CVg / CVe) was 0.566 for leaf blight. This value suggests a condition unfavorable to selection for resistance to the character. It is believed that the use of traditional breeding methods may have low efficiency in improving the level of resistance of the population into focus (ALVES, 2004). In this context, it is suggested that the process of development of carrot cultivars for use in organic systems is initially conducted in conventional systems, since these it is possible to use more efficient alternatives for inoculation of the disease. In this strategy, the most promising populations were tested in different agro-ecological farming systems only from the validation phase.

According to the analysis of variance of data obtained from testing conducted in Rural Core Taguatinga (OA), significant effects for families were observed for the characters COMP, $\mathrm{a}^{*} \mathrm{X}, \mathrm{a}^{*} \mathrm{~F}$ and $\mathrm{TP}$, and the coefficients variation were low for all traits (ranging from 4.043 to $9.749 \%$ ). However, at 90 days after sowing, was not possible to visualize differences in symptoms between the plots for the character of burning leaves.

At Rural Core Taguatinga (OA) there was no occurrence of CRACK and was observed an average content of boron (B) from $0.20 \mathrm{mg} \mathrm{dm}^{3}$ soil test; value higher than the content of $\mathrm{B}$ in Mokiti Okada Foundation (NA) $\left.(0.05 \mathrm{mg} \mathrm{dm})^{3}\right)$, in which the character CRACK did not show significance. According Filho, Souza and Silva (2005), the appropriate content of boron in the soil to produce roots of marketable carrots without cracks is 0.45 to $0.55 \mathrm{mg} \mathrm{kg}^{-1}$.

There was significant for the character to $\mathrm{a}^{*} \mathrm{~F}$, a fact which was not observed in the system of Natural Agriculture (NA). This suggests that the assessment system of this character in Organic Agriculture (OA) has a greater chance of success in identifying superior genotypes compared to the system of Natural Agriculture (NA).

According to Table 1, it appears that for most of traits the heritability values ranged from medium to high, similar to values found by Vieira et al. (2009). For the characters $a^{*} X$ and $a * F$ the literature contains some different values (SANTOS; SIMON, 2006). This difference in observed values may be due to the fact that heritability is a property not only of character but also to the public and the environment to which individuals are embedded. The heritability values obtained in the test performed in organic farming system (OA) for the characters $a^{*} X$ and $a^{*} F$ were several orders of magnitude higher than those generated on the Natural Agriculture (NA). These results suggest that evaluation of carrot genotypes for the characters to $\mathrm{a}^{*} \mathrm{X}$ and $\mathrm{a} * \mathrm{~F}$ in the cropping system $\mathrm{OA}$ has a greater chance of success than if performed in the cropping system NA. Likewise, the ratio CVg / CVe for the character $\mathrm{a}^{*} \mathrm{X}$ has the values larger than 1 , which shows a favorable condition since selection of the variance exceeds the environment (VENCOVSKY, 1987). Note that the system of cultivation for Organic Agriculture (OA) at 90 days after sowing, it was not possible to visualize differences in symptoms between the plots for the character LB.

The estimated genetic gain cycle using three different intensities of selection $(10,20,30 \%)$ for the tests carried out in Mokiti Okada Foundation NA and Rural Core Taguatinga - OA, that are shown in Table 2, indicate that the gains for the character COMP in both agroecologic systems, OA and NA, are similar since the heritability values obtained for each system were of similar magnitude. Furthermore, these gain values do not differ from the estimates obtained for this character in conventional systems, namely, Silva and Vieira (2010a) $8,57 \%$ (50\% intensity selection); and in organic system $11,58 \%$ (50\% intensity selection). This suggests that selection for this trait can be performed either in agroecological systems or conventional cultivation.

As for the characters $\mathrm{a}^{*} \mathrm{X}$ and $\mathrm{a} * \mathrm{~F}$ it appears that the estimates of gain derived from information from the agroecosystem NA are much lower than those obtained in agroecosystem OA. This fact is directly related to the estimates of heritability for these characters. Thus, it is suggested the use of the agroecosystem OA for genotype evaluation in order to select those with highest values of a ${ }^{*}$. The gains for the characters $\mathrm{a}^{*} \mathrm{X}$ and $\mathrm{a}^{*} \mathrm{~F}$ in organic agriculture system, are similar to those obtained in conventional systems by Silva and Vieira (2010b) with $7,82 \%$ to $\mathrm{a} * \mathrm{X}$ and 2,98 to $\mathrm{a} * \mathrm{~F}$, using $10 \%$ intensity selection. 
Table 2. Estimated gain per cycle (GS), with three selection intensities $(10 \%, 20 \%, 30 \%)$ for plant traits of carrot in two agro-ecological farming systems: Natural Farming System of cultivation - NA (Foundation Mokiti Okada) and Organic Agriculture System farming - OA (Rural Core Taguatinga).

\begin{tabular}{|c|c|c|c|c|c|c|}
\hline & \multicolumn{6}{|c|}{ Selection Intensities } \\
\hline & $10 \%$ & $20 \%$ & $30 \%$ & $10 \%$ & $20 \%$ & $30 \%$ \\
\hline & \multicolumn{3}{|c|}{ Natural Agriculture - AN } & \multicolumn{3}{|c|}{ Organic Agriculture - $\mathrm{AO}$} \\
\hline & \multicolumn{6}{|c|}{ GS $(\%)^{*}$} \\
\hline COMP & 11.0 & 8.77 & 7.27 & 9.35 & 7.46 & 6.18 \\
\hline$a * X$ & 3.66 & 2.92 & 2.42 & 10.19 & 8.12 & 6.73 \\
\hline$a^{*} \mathrm{~F}$ & 0.65 & 0.52 & 0.43 & 4.17 & 3.32 & 2.75 \\
\hline LB & 3.4 & 2.71 & 2.25 & - & - & - \\
\hline CRACK & 14.49 & 11.56 & 9.57 & - & - & - \\
\hline
\end{tabular}

COMP: average root length per plot $(\mathrm{cm}), \mathrm{a}^{*} \mathrm{X}$ : the $\mathrm{a}^{*}$ average color of the xylem per plot, $\mathrm{a}^{*} \mathrm{~F}^{*}$ : the a* average color to the phloem per plot, LB: leaf blight and CRACK: crack. * Estimates of genetic gain due to selection for the character.

In $\mathrm{LB}$ character, it appears that the genetic gains expecte

$\mathrm{d}$ are of low magnitude for the different selection intensities. This may also be associated with low inoculum pressure during the evaluation period in the experimental area of the Foundation Mokiti Okada, due to the small genetic variability $(3.09 \%)$ of the population used for this character (Table 1).

The fact that the selected roots must be cut and evaluated to quality traits, possibly involve the use of lower intensities of selection (e.g., 30\%) in order to ensure a suitable population size in the process subsequent recombination of the selected families, due not to be allowed to use any pesticide to reduce the loss of roots after the refrigeration process. It's important to note that the process of development of cultivars resistant to leaf blight for use in organic systems must be initially treated in conventional systems, since these it is possible to use more efficient alternatives for inoculation of the disease, which allow to maximize the efficiency the selection process. In this strategy, the most promising populations were tested in different agroecological farming systems only from the validation phase.

As regards the character CRACK, it appears that the estimated expected genetic gains were slightly higher compared to that found for other traits in the culture system NA (Table 2). Considering the low magnitude of heritability values and $\mathrm{CVg} / \mathrm{CVE}$ ratio, it is suggested that the selection to reduce the expression of this trait should be preceded by the use of methods that guarantee greater character expression and greater environmental control in order to guarantee the quality of the traits. estimates obtained. Thus, it is recommended that the system of natural agriculture (NA) be used for the evaluation of genotypes with regard to the characteristic of cracking.

\section{CONCLUSIONS}

The low magnitude of heritability estimates for traits related to root color, indicate the need for improvement in breeding process to maximize the gains of the selection process. The magnitude of the estimates of heritability and selection gains obtained for root traits evaluated in agroecological farming systems was similar to estimates found in conventional systems of production. This suggests that the selection of these characters may be performed in conventional systems or agroecological cultivation.

Largest selection gains can be expected to crack incidence and root length characters in the system NA and for parameter $\mathrm{a}^{*}$ and length of roots in the OA system.

RESUMO: A cenoura está entre as hortaliças mais plantadas no Brasil, o que representa importância no mercado nacional. Essa cultura pode ser cultivada em sistemas convencionais e agroecológicos, sendo importante o desenvolvimento de estudos para melhorar características de produtividade, resistência a doenças e qualidade de raiz em sistemas com base agroecológica de cultivo. O objetivo do presente trabalho foi estimar parâmetros genéticos que fornecem uma estratégia de melhoramento na busca pelo desenvolvimento de novas variedades de cenoura adaptadas às condições do cultivo agroecológico do Distrito Federal. Considerando dados de testes realizados em áreas de cultivo agroecológico (Agricultura Natural - NA e Agricultura Orgânica - OA), foram avaliadas as seguintes características: incidência de queima das folhas - LB, incidência de rachadura radicular - RACH, comprimento de raiz - COMP, formato de raiz - TP, formato do ombro -TO, 
Genetic parameters...

VILELA, M. S. et al.

medida da cor do parâmetro $\mathrm{a} *$ do xilema $-\mathrm{a}^{*} \mathrm{X}$, medida da cor do parâmetro a *do floema $-\mathrm{a}^{*} \mathrm{~F}$. As características foram avaliadas em 100 progênies de meios-irmãos derivadas da cultivar Brasília, usando um delineamento de blocos inteiramente casualizados. Para os caracteres COMP, a*X, a*F, TP e TO, a interação tratamento $\mathrm{X}$ ambiente foi significativa de acordo com os resultados do teste $\mathrm{F}$. Os valores das análises de variância individuais apresentaram efeito significativo para as seguintes características: COMP, a*X, TP, TO, LB para o sistema NA e COMP, a*X, um a*F, TP para o sistema OA. No sistema NA, os valores de estimativa de herdabilidade - $\mathrm{ha}^{2}$ para os caracteres da planta variaram de 65,66 a 25,52\% e, no sistema OA, o ha da característica $\mathrm{a} * \mathrm{X}$ foi de $81,13 \%$. As estimativas de ganho genético por ciclo para os caracteres $\mathrm{a}^{*} \mathrm{X}$ e $\mathrm{a}^{*} \mathrm{~F}$ foram menores no sistema NA do que as estimativas observadas no sistema OA.

PALAVRAS-CHAVE: Daucus carota. Herdabilidade. Melhoramento genético.

\section{REFERENCES}

AGUILLAR, J. A. E.; REIFSCHNEIDER, F. J. B.; PESSOA, H. B. S. V. Época de início de aplicação de fungicidas para o controle de queima-das-folhas de cenoura. Horticultura Brasileira, Brasília, v. 4, n. 11, p. 41, 1986.

ALVES, J. C. S. Estimativa de parâmetros genéticos para caracteres de semente e de planta em populações de cenoura (Daucus carota $L$.) derivadas da cultivar Brasília. Dissertação (Mestrado em Ciências Agrárias) - Universidade de Brasília, Brasília, 2004.

ANDRADE, L. M. S.; BERTOLDI, M. C. Atitudes e motivações em relação ao consumo de alimentos orgânicos em Belo Horizonte, MG. Brazilian Journal of Food Technology, Campinas, v. 15, p. 31-40, 2012. https://doi.org/10.1590/S1981-67232012005000034

CARDOSO, A. I. I.; JOVCHELEVICH, P.; MOREIRA, V. Produção de sementes e melhoramento de hortaliças para a agricultura familiar em manejo orgânico (seed production and vegetables breeding for smallholder farming in organic management). Revista Nera, Presidente Prudente, n. 19, p. 162-169, 2012.

CRUZ, C. D. GENES - A software package for analysis in experimental statistics and quantitative genetics. Acta Scientiarum, v. 35, n. 3, p. 271-276, 2013. https://doi.org/10.4025/actasciagron.v35i3.21251

FILHO, M. V. de M.; SOUZA, A. F.; SILVA, H. R. da. Nível crítico de boro em cenoura cultivada em um solo sob cerrado. Horticultura Brasileira, Brasília, DF, v. 23, n. 1, 2005.

https://doi.org/10.1590/S0102-05362005000100014

LOPES, P. R.; LOPES, K. C. S. A. Sistemas de produção de base ecológica-a busca por um desenvolvimento rural sustentável. Revista Espaço de Diálogo e Desconexão, Limeira, v. 4, n. 1. 2011.

MAROUELLI, W. A.; OLIVEIRA, R. A.; SILVA, W. L. C. Irrigação na cultura da cenoura. Embrapa Hortaliças, Brasília. 14p. (Circular Técnica, 48), 2007.

PEREIRA, A. S. Teores de carotenóides totais em cenoura (Daucus carota L.) e sua relação com a coloração das raízes. Tese (Doutorado) - Universidade Federal de Viçosa, Viçosa, 2002.

PEREIRA, R. B.; SILVA, G. O. da; PINHEIRO, J. B.; CARVALHO, A. D. F. de; VIEIRA, J. V. Herdabilidade e resposta à seleção para peso de raízes e tolerância a queima-das-folhas em populações de cenoura. Embrapa Hortaliças - Boletim de Pesquisa e Desenvolvimento (INFOTECA-E), 2012.

RESENDE, F. V.; VIEIRA, J. V.; VIDAL, M. C. Avaliação de populações de cenoura do programa de melhoramento da Embrapa Hortaliças em sistema orgânico de produção. Horticultura Brasileira, Brasília, DF, v. 23, 2005. 
RESENDE, G. M.; BRAGA, M. B. Produtividade de cultivares e populações de cenoura em sistema orgânico de cultivo. Horticultura Brasileira, Recife, v. 32, n. 1, p. 102-106, 2014.

https://doi.org/10.1590/S0102-05362014000100017

SANTOS, C. A. F.; SIMON, P. W. Heritabilities and minimum gene number estimates of carrot carotenoids. Euphytica, Dordrecht, v. 151, p. 79-86, 2006. https://doi.org/10.1007/s10681-006-9130-7

SILVA, G. O.; VIEIRA, J. V.; VILELA, M. S.; REIS, A.; BOITEUX, L. S. Parâmetros genéticos da resistência ao complexo da queima-das-folhas em populações de cenoura. Horticultura Brasileira, Recife, v. 27, n. 3, p. 354-356, 2009. https://doi.org/10.1590/S0102-05362009000300017

SILVA, G. O. de; VIEIRA, J. V. Relações entre caracteres de cenoura para sistemas de cultivos orgânico e convencional. Ceres, Viçosa, 57, n. 5, p. 665-672, 2010a. https://doi.org/10.1590/S0034-737X2010000500016

SILVA, G. O. de; VIEIRA, J. V. Seleção e número mínimo de famílias para avaliação de parâmetros de cor em uma população meio-irmã de cenoura. Ceres, Viçosa, 57, n. 1, p. 66-72, 2010b. https://doi.org/10.1590/S0034$\underline{737 X 2010000100012}$

VAN BUEREN, L.; Hulscher, M.; Haring, M.; Jongerden, J. P.; van Mansvelt, J. D.; den Nijs, A. P. M.; Ruivenkamp, G. T. P. Sustainable organic plant breeding: Final report-a vision, choices, consequences and steps. Vormgeving: Fingerprint, 1999, 60p.

VENCOVSKY, R. Herança quantitativa. In: PATERNIANI, E. \& VIEGAS, G. P. (Ed.). Melhoramento e produção de milho no Brasil. 2ed. Campinas: Fundação Cargil, 1987.

VIEIRA, J. V.; REIS, A.; LOPES, C. A.; CHARCHAR, J. M.; NASCIMENTO, W. M.; LANA, M. M.; FONSECA, M. E.; FINGER, F. L.; CARVALHO, F. de A.; NETO, J. C.; PEIXOTO, J. R.; RESENDE, F. V.; VALLE, J. C. V.; TOMITA, C.; PIRES, J.; MORI, E. K.; SILVA, J. B. C.; MEROLA, J. O.; BOITEUX, L. S.; MARQUES, C.; UTUMI, M. M. Desenvolvimento de cultivares e populações de cenoura com resistência às principais doenças e melhor qualidade de raiz fase II. Brasília, DF: Embrapa Hortaliças, 2007.

VIEIRA, J. V.; SILVA, G. O.; BOITEUX, L. S.; SIMON, P. W. Divergência genética entre acessos de cenoura pertencentes a grupos varietais distintos utilizando caracteres morfológicos. Horticultura Brasileira, Recife, v. 27, n. 4, p. 473-477, 2009. https://doi.org/10.1590/S0102-05362009000400012 